p-ISSN 1693-1246

e-ISSN 2355-3812

January 2019
Jurnal Pendidikan Fisika Indonesia 15 (1) (2019) 46-51

DOI: 10.15294/jpfi.v15i1.15389 http://journal.unnes.ac.id/nju/index.php/jpfi

\title{
Effectiveness of DILA Learning Model Application on Applied Physics Course in The Department of Mining Engineering
}

\author{
Fadhilah $^{1 *}$, Z. M. Effendi², Ridwan², M. Alias ${ }^{3}$ \\ ${ }^{1}$ Jurusan Teknik Pertambangan, Fakultas Teknik, Universitas Negeri Padang, Indonesia \\ ${ }^{2}$ Program Studi Pendidikan Teknologi Kejuruan, Fakultas Teknik, Universitas Negeri Padang, Indonesia \\ ${ }^{3}$ Fakulti Pendidikan Teknikal dan Vokasional, Universiti Tun Hussein Onn Malaysia
}

Submitted: 18 July 2018. Revised: 29 December 2018. Accepted: 1 January 2019

\begin{abstract}
There is the fact that the students' learning outcome in Applied Physics course related to the application of the mining industry is unsatisfactory. Based on the results of the final score, the rate of successful students was only around $40 \%$. Moreover, students' understanding application is also not by the desired competencies. In this research, a learning model was developed from the Contextual Teaching and Learning Model (CTL), i.e., DILA model which consists of four syntaxes (Display, Inquiry, Learning Community, and Authentic Assessment). The effectiveness of the DILA learning model was investigated to improve students' learning outcomes in the Applied Physics course. This research employed the quasi-experimental design where the experimental class was treated by DILA model based on Contextual Teaching and Learning; whereas control class was not treated by the model. Data were obtained from the results of the pre-test and post-test scores; then it was analyzed by a parametric with an independent t-test, related t-test, and the effect size. The results indicate that there was a significant increase in students' learning outcomes in the experimental class compared to the control class. In conclusion, DILA model can improve students' learning outcomes in the Applied Physics course effectively.
\end{abstract}

\begin{abstract}
ABSTRAK
Hasil belajar Fisika Terapan yang diperoleh mahasiswa yang terlihat dari nilai akhir semester dan penerapan pada industri pertambangan pada umumnya tidak memuaskan. Tingkat kelulusan mahasiswa hanya sekitar $40 \%$. Sehingga pemahaman mahasiswa dalam penerapannya juga tidak sesuai dengan kompetensi yang diinginkan. Model DILA merupakan salah satu model pembelajaran yang dikembangkan dari Model Contextual Teaching and Learning (CTL). Model DILA terdiri atas empat sintaks yaitu: Display, Inquiry, Learning Community, dan Authenthic Assessment. Penelitian ini ditujukan untuk mengukur efektifitas Model Pembelajaran DILA guna meningkatkan hasil belajar mahasiswa pada matakuliah Fisika Terapan. Penelitian ini merupakan quasi eksperiment dimana kelas eksperimen diberikan pembelajaran dengan Model DILA berbasis Contextual Teaching and Learning. Data diperoleh dari hasil pre-test dan post-test dan diolah secara parametric dengan $t$ test sample independent dan $t$ test related serta effect sizenya. Hasil penelitian ini menunjukkan bahwa model pembelajaran DILA yang diterapkan pada matakuliah Fisika Terapan di Jurusan Teknik Pertambangan adalah efektif. Ini berarti model Pembelajaran DILA dapat meningkatkan hasil belajar mahasiswa pada matakuliah Fisika Terapan.
\end{abstract}

Keywords: Applied Physics Course; Contextual Teaching; Learning; DILA Learning Model; Students' Learning Outcomes

\section{INTRODUCTION}

Physics is a study which can raise the attention to understand the natural phenomena in the environment. Learning in Physics is

*Correspondence Address:

Kampus Air TawarPadang 25131

E-mail: fadhilah@ft.unp.ac.id not only to study the facts, concepts, principles, and laws but also to learn how to obtain information, to apply steps in the scientific work, science, and technology (Chapman, 1955). Moreover, Physics in the higher education level students are needed to learn about knowing (what) as well as to study the causes and consequences (why).

Physics is the basis for engineering 
science where Applied Physics is a basic course in science engineering. As an applied study, the integration of theory and application is needed to improve students' skills. There are differences in the example of use in Applied Physics learning among the Department of Mining Engineering, Mechanical Engineering, Electrical Engineering, and Civil Engineering majors.

In some higher education institutions, Applied Physics learning usually provides a general example of application. Therefore, the skills of students related to the study field are difficult to obtain optimum results. Regarding this problem, the contextual teaching and learning as a learning concept can help teachers to integrate the study material with the phenomena and situations in the environment. This learning model can encourage students to make connections between their knowledge and application in their lives as a member of the family and community (Johnson, 2014).

In Indonesia, the contextual teaching and learning (CTL) model have seven basic principles, i.e., constructivism, inquiry, questioning, learning community, modeling, reflection, and authentic assessment (Rusman, 2014). CTL does not have its own syntax in its implementation and with various strategies such as "RANGKA" which stands for Rumuskan (Formulate), Amati (Observe), Nyatakan (Express), Gabungkan (Combine), Komunikasikan (Communicate), and Amalkan (Practice) (Suryawati, Osman,\& Meerah, 2010); and REACT which stands for Relating, Experiencing, Applying, Cooperating, and Transferring (Crawford, 2001)

Based on the Standard of Learning Process by Ministry of Research, Technology, and Higher Education (Permenristekdikti) Article 10 Number 44 Year 2015, the characteristics of the learning process include interactive, holistic, integrative, scientific, contextual, thematic, effective, collaborative, and student-centered learning (Sutrisno \& Suyadi, 2015). Standard of Learning Process by Ministry of Research, Technology, and Higher Education (Permenristekdikti) Article 10 Number 44 Year 2015 suggests a shift in the paradigm of the learning system, from teacher-centered learning (TCL) to student-centered learning (SCL). Therefore, CTL is a suitable model to use in the learning process.

The fact that Applied Physics learning is more TCL than SCL, and students have difficulties with the application of Applied Physics material in the Mining industry is exciting to be studied. The change from TCL to SCL in Applied Physics learning indeed requires proper planning such as by developing a model to achieve meaningful learning goals.

In this study, DILA model which consists of four syntaxes, i.e., Display, Inquiry, Learning Community, and Authentic Assessment (Fadhilah, Mawardi, \& Ridwan, 2017) was employed to help the transformation of TCL to SCL as the development of contextual teaching and learning (CTL). This model aims to provide contextual learning following the expected expertise. For example, in Applied Physics subjects for Mining Engineering, the learning will be conducted by the application in the mining industry.

In the DILA model, the principle of constructivism can be seen at the display stage. Students build their knowledge from the knowledge they have by paying attention to the video application of the material in the mining industry. The principles of inquiry, questioning and modeling are summarized in the Inquiry stage. Students find concepts about the material to learn by asking questions, conducting experiments and answering questions. The principle of the learning community is in line with the stages of a learning community which is in the model development syntax. The principle of reflection is incorporated into the learning community because students respond to what they learn through discussion in solving problems. The authentic assessment principle is applied completely in the last stage of this development model syntax.

DILA model has strengths compared to the development of other CTL models such as RANGKA and REACT. DILA model has simplified syntax in describing the seven principles of the CTL learning model; students can immediately see the application of the material contextually at the display and authentic assessment stages.

Therefore, theoretically, DILA model is very suitable for the applied science subject learning. The effectiveness of the DILA model in Applied Physics course in the Mining Engineering Department to improve students' learning outcomes was investigated in this research.

\section{METHOD}

The research employed a quasi-experimental with pre-test and posttest design (Creswell, 2012) which was conducted in the D3 Mining Engineering study program at the Faculty 
of Engineering, Universitas Negeri Padang, Indonesia. The subject of this study was the 50 students enrolled in the Applied Physics course with 16 times of meeting. DILA learning model was applied in the experimental class whereas the control class experienced general teaching and learning model by lecture. The students' learning outcomes between experimental and control classes were measured, and the effectiveness of the model was determined. Also, the assessment of learning outcomes was also based on the results of the midterm exam, final exam, and practicum.

Data were obtained from the score of pre-test and post-test in the experimental and control classes. The pre-test was given at the beginning of Applied Physics learning, while the post-test was performed at the end of the lecture.

Then, data of pre-test and post-test results were processed using SPSS version 16 . The homogeneity and normality of research subject are necessary to carry out t-test. The homogeneous requirements can be fulfilled if $\mathrm{F}_{\text {value }}<\mathrm{F}_{\text {table }}$. The t-test performed an independent sample t-test (Beins \& Carthy. 2012). The results of T-test were significant if $t_{\text {value }}<t_{\text {table }}$ at p 0.05 .

The pre-test was conducted in both classes to measure the initial concept mastery of students. In case both classes have the homogeneous variant and normal, as well as the same initial ability (proven by the t-test), then both classes can be divided as the control class and the experimental class. The control class was given the conventional learning of Applied Physics, where the learning was conducted in a lecture, and the determination of student ability was based on the results of student examinations. The experimental class was treated by DILA learning model with display, inquiry, learning community, and authentic assessment syntaxes.

In the Display stage, the lecturer explained the learning outcome and learning achievement indicators, and then displayed the video application material in the mining industry related to the material to be studied. Students observed and built their knowledge by associating the video with their knowledge.

In the Inquiry stage, the lecturer delivered questions to students about the video that was played with the material to be studied. Students found the concept of learning material. Moreover, students demonstrated their understanding related to the learning material in front of the class. This demonstration could be obtained through the internet or personal ideas from reading the learning material. Then some concepts from the material were obtained from this demonstration. The demonstration was carried out by students who have been notified one week before learning was given. Students were given the subject topic to be discussed in the following week of the meeting. Then, the students were asked to demonstrate the material for the next week according to the learning experience they have.

At the Learning Community stage, the lecturer and students concluded the learning material and students were divided into several groups to solve problems regarding learning materials related to the mining industry. Questions were given during lectures according to the lecturer guidance. Students were allowed to collaborate in solving problems. The experimental class consisted of 31 students, and it was divided into 10 groups.

In the Authentic Assessment stage, the lecturer assessed the cognitive, affective and psychomotor abilities of students by giving tests for cognitive aspect, filling observation instruments for affective aspect, psychomotor assessment, and filling out assessment rubrics for project assignments. The cognitive aspect was measured by answering post-test questions ( 30 objective questions that have been tested first). All of these questions represent Bloom taxonomy by the cognitive domain.

A post-test was given to both classes after 16 meetings on the lecture. The same question item was given to the experimental class with the control class, regarding all the material that has given for one semester. The post-test results were also calculated for normality and homogeneity. Then, the t-test was carried out.

\section{RESULTS AND DISCUSSION}

The control class with 19 students showed the average pre-test score (M) at 29.26 with a standard deviation (SD) 9.24. The experimental class with 31 students showed a pre-test score average at 29.80 and SD 11.02 (Table 1).

The results of the pretest were analyzed to determine the normality and homogeneity of both classes and to examine whether the initial abilities of students in the two classes were the same or not. Both classes showed that normality $>0.05$ indicates that it was normal. Therefore, homogeneity tests could be carried out. 
Table 1. Results of Pre-test Data Processing

\begin{tabular}{lcccccc}
\hline Class & $\mathrm{N}$ & $\mathrm{M}$ & $\mathrm{SD}$ & Normality & Homogeneity & $\mathrm{t}$ \\
\hline Control & 19 & 29.26 & 9.24 & 0.217 & $\mathrm{~F}_{\text {value }}=1.42$ & $\mathrm{t}_{\text {value }}=0.23$ \\
Experiment & 31 & 29.80 & 11.02 & 0.28 & $\mathrm{~F}_{\text {table }}=2.014$ & $\mathrm{t}_{\text {table }}=1.679$ \\
\hline
\end{tabular}

Table 2. Post-test Data Processing Results

\begin{tabular}{lccccccc}
\hline Class & $\mathrm{n}$ & $\mathrm{M}$ & $\mathrm{SD}$ & Normality & Homogeneity & $\mathrm{T}$ & $\mathrm{d}$ \\
\hline Control & 19 & 56.1 & 11.2 & 0.935 & $\mathrm{~F}_{\text {value }}=1.558$ & $\mathrm{t}_{\text {value }}=2.79$ & \multirow{2}{*}{0.82} \\
Experiment & 31 & 66.7 & 13.98 & 0.226 & $\mathrm{~F}_{\text {table }}=2.014$ & $\mathrm{t}_{\text {table }}=1.679$ & 0.82 \\
\hline
\end{tabular}

The homogeneity test showed $\mathrm{F}_{\text {value }}<\mathrm{F}$ table meaning that the two classes have homogeneous variances. After both classes were categorized as normal and homogeneous, then the t-test was carried out. The result of the ttest showed $t_{\text {value }}<t_{\text {table }}$. Therefore, both classes significantly have the same initial ability.

Effect Size (d) was calculated to see how much influence the treatment given to the experimental class. The criteria proposed by Cohen about the size of the effect size are as bellow (Beins \& Carthy, 2012:191):

$0<\mathrm{d}<0.2$ Small Effect

$0.2<\mathrm{d}<0.8$ Medium Effect

$d>0.8$ Large Effect

The post-test results were analyzed to determine the normality and homogeneity of classes to allow in performing a significant test. The normality test was carried out with SPSS version 16 using the Kolmogorov-Smirnov test. Both classes showed values $>0.05$ indicating a normal distribution. The homogeneity test showed $F_{\text {value }}<F_{\text {table }}$ thus two classes have homogeneous variances. After these normal and homogeneous conditions are matched, an independent sample t-test can be performed (Beins \& Carthy. 2012). The results of the t-test showed $t_{\text {value }}>t_{\text {table }}$ indicating differences in the acquisition of learning outcomes significantly with $p 0.05$. Effect size (d) 0.82 meaning that this difference has a large effect on learning outcomes between the control class and the experimental class (Table 2). The effect of giving treatment to the experimental class was noticed from the difference between the results of the pre-test and the post-test results. The ttest of sample related (Beins \& Carthy, 2012) was used to see the effect of the DILA learning model application in Applied Physics course on students' learning outcomes.

The results of data analysis showed $t_{\text {va. }}$ lue $>t_{\text {table }}$ where the administration of treatment caused a very significant increase in learning outcomes by 36.9 points. Effect size (d) with a value of 2.18 indicates the significant difference in the effect of the DILA learning model on students' learning outcomes (Table 3). $\mathrm{N}$ represents the number of samples, $M$ shows the average value, $S D$ is the standard deviation, $t$ shows the results of $t$ and $d$ test shows the value of effect size.

Overall, the results of this research indicate the effectiveness of the DILA Learning Model in learning Applied Physics. Each syntax in the DILA model is by the existing learning theory, especially to information processing theory. In this research, the stage of Display learning, the learning step includes the lecturer explanation on the syllabus, learning outcomes and indicators of learning achievement. Then, the lecturer displayed a video about the application of learning material in the mining industry. It was expected that by watching this video, students could associate the knowledge they have obtained with the application shown. By the theory of cognitive information processing, Muijs \& Reynolds (2008) stated that stimuli could be obtained from the senses of sight, hearing or other senses. It will provide initial perceptions that will be stored and processed according to the existing knowledge. Early knowledge in teaching helps students to build the bridges for connecting between new knowledge and existing knowledge. The results of the study by Amin, Kamaruddin, Ahmad, \& Alias, 2011 stated that the application of contextual videos for learning is more effective than learning without video.

The stage of inquiry learning involves students to think critically and creatively. In this strategy, the lecturer gave questions related to the video that was played; then students could find a connection with the material to be studied. The following step, students demonstrated the experiment by the material and the lecturer provided an opportunity for students to develop their ideas to find concepts in learning material. 
Table 3. Results of Experimental Class Data Processing

\begin{tabular}{llllll}
\hline & $\mathrm{N}$ & $\mathrm{M}$ & $\mathrm{SD}$ & $\mathrm{t}$ & $\mathrm{d}$ \\
\hline Pre-test & 31 & 29.80 & 11.02 & $\mathrm{t}_{\mathrm{h}}=11.96$ & \multirow{2}{*}{2.18} \\
Post-test & 31 & 66,7 & 13.98 & $\mathrm{t}_{\text {table }}=2.042$ & \\
\hline
\end{tabular}

Learning is a process of thinking (Wina, 2006). At the inquiry stage, students were asked and conducted experiments by the learning material. According to Brunner (Warsita, 2008), a person's cognitive development occurs through active, iconic and symbolic stages. Abdi (2014) carried a study by providing inquiry-based learning in the experimental class. Learning outcomes in the experimental class were higher than the control class. Sinuraya (2016) also carried out inquiry-oriented in General Physics learning. The results of the study prove that inquiry-oriented learning increased learning outcomes. Almuntasheri, Gillies, \& Wrightl (2016) conducted a guided inquiry in learning about density. Students who have guided inquiry learning could understand concepts and explain density concepts better than students who did not experience a guided inquiry. The results of the study by Fayakun \& Joko (2015) using the method of predict, observe, explain (POE) as a learning method with the three main steps of the scientific method as the key to the inquiry stage of CTL showed that it improved students' high-level thinking skills.

The stages of learning community stimulated the students to work in teams. The learning step in realizing this strategy was; lecturers divided students into heterogeneous groups, and they concluded about the material that had been studied. Lecturers gave the assignments that were completed in groups. At the end of the lecture, each of these groups presented their project assignments by the material provided. In correlation with the mining industry, collaboration in teams are necessary. Solid teamwork will give good results of work. At this stage, students collaborated to apply teaching materials to solve problems. By this method, students were more open with their friends in solving problems (Panitz,1999). Gregor (1992), Laal (2012) stated that collaborative learning involves joint intellectual endeavors by students, or students and teachers together in discussion, creation, and decision making.

The stages of learning authentic assessment are manifestations of learning assessment standards that have one of authentic principle (Permenristekdikti No. 44 Year 2015 Article 20). Assessment is oriented to a con- tinuous process and learning outcomes that reflect students' abilities when the learning process takes place. Authentic assessment is a form of assessment that requires students to carry out real-world tasks that show a meaningful application of an essential knowledge or skill (Ismet \& Hariyanto, 2014).

The DILA learning model has simple syntaxes and can produce meaningful learning because it is based on CTL. CTL motivates students to make correlation and relation that express meaning. Alfred North Whitehead states that the child must make it (their ideas) their own and must understand its application in real-life situations at the same time (Johnson, 2014).

Based on the description of the learning steps, the DILA model is very close to the scientific approach with the goals of the 2013 curriculum. Scientific approach is a learning process designed to make students actively construct concepts, laws or principles through the stages of observing (to identify or find problems), formulate problems, submit or formulate hypotheses, collect data with various techniques, analyze data, draw conclusions and communicate concepts, laws or principles that are "discovered". In addition to providing physics learning in the form of theory, the teacher also has to teach how to discover science scientifically (Kabil, 2015).

The scientific approach generally contains a series of data collection activities through observation and experimentation, processing information or data, analyzing, then formulating, and testing hypotheses (Mudlofir \& Rusyidah, 2016). The syntax in the DILA learning model is in line with the learning steps using this scientific approach.

One example the DILA model application is in learning material on Magnitude and Units. Teachers can display videos about the activities of excavating and filling the dump truck by excavators. Students will think about how to determine the number of excavator buckets to fill one dump truck. Then demonstrate about measuring a box. They see that measurement is always followed by uncertainty. After knowing the size of the box, they calculate the volume. Here they understand how to convert 
units from yard ${ }^{3}$ to $\mathrm{m}^{3}$ for volume and convert $\mathrm{Lb}$ to Ton. Issues provided are also related to the mining industry. For example, calculating the dump truck bucket capacity in units of Ton or $\mathrm{m}^{3}$ does not matter anymore as long as it is known the density of the material carried.

\section{CONCLUSION}

DILA learning model with Display, Inquiry, Learning community and Authentic Assessment can be used as an alternative learning model in Applied Physics course. This learning model requires student-centered learning, contextual, collaborative, and an effective learning system with a scientific approach and authentic assessment. DILA learning model is effective to improve the students' learning outcomes in Applied Physics course proven by the results of the post-test score between the control class and experimental class. Significantly, the experimental class had a higher average score compared to the control class. It is recommended for lecturer of Applied Physics subjects to use the DILA learning model as an alternative learning model in lectures.

\section{REFERENCES}

Abdi, A. (2014). The Effect of Inquiry-based Learning Method on Students' Academic Achievement in Science Course. Universal Journal of Educational Research, 37-41.

Almuntasheri, S., Gillies, R. M., \& Wright, T. (2016). The Effectiveness of a Guided Inquiry-based, Teachers' Professional Development Programme on Saudi Students' Understanding of Density. Science Education International, 16-39.

Amin, Z. Md., Kamruddin, Nafisah K. Md., Ahmad, W. M., \& Alias M (2011). Impact of Contextual Video in Learning Engineering Statistics in The Universiti Tun Hussein Onn Malaysia (UTHM). International Journal of Arts \& Sciences, 4(11), 195-202.

Warsita, B. (2008). Teknologi Pembelajaran, Landasan dan Aplikasinya. Jakarta: Rineka Cipta.

Beins, B. C., \& Carthy, M. A. (2012). Research Methods and Statistics. New Jersey: Pearson Edcation.

Chapman. S. (1955). How to Study Physics. In Donald Simanek's Page. Retrieved from http://www.physics.csbsju.edu/105/HowToStudyPhysics.htm.

Crawford, M.L. (2001). Teaching contextually: Research, rationale, and techniques for improving student motivation and achievement in Mathematics and Science. Texas: CORD.

Creswell, J. W. (2012). Educational Research: planning, conducting, and evaluating quantitive and qualitative research. (4 $4^{\text {th }}$ ed). Boston USA: Pearson Education. Inc.

Fadhilah, Z., Mawardi E., \& Ridwan. (2017). Analysis of contextual teaching and learning (CTL) in the course of applied physics at the mining engineering department. Int. J. Sci. Appl. Sci, Conf. Ser. 1(1), 25-32.

Fayakun, M., \& Joko P. (2015). Efektifitas Pembelajaran Fisika Menggunakan Model Kontekstual (CTL) dengan Metode Predict, Observe, Explain terhadap Kemampuan Berpikir Tingkat Tinggi. Jurnal Pendidikan Fisika Indonesia, 11 (1), 49-58.

Gregor, B. L. (1992). What Is Collaborative Learning? Retrieved from https://www.researchgate.net/publication/242282475.

Ismet, B., \& Hariyanto (2014). Asesmen Pembelajaran. Bandung: PT. Remaja Rosdakarya.

Johnson, E. B. (2014), Contextual Teaching and Learning: Menjadikan kegiatan belajar-mengajar mengasyikkan dan bermakna. (I. Setiawan, \& I. Sitompul, Trans). Bandung: Kaifa.

Jurubahasa, S. (2016). Inquiry-Oriented Learning Material to Increased General Physics Competence Achievement. Journal of Education and Practice. 7(28).

Kabil, O. (2015). Philosophy in physics education. Procedia - Social and Behavioral Sciences. 197, $675-679$.

Laal, M. L. (2012). Collaborative learning: what is it? Procedia - Social and Behavioral Sciences, 491-495.

Mudlofir, A., \& Rusydiyah, Evi F. (2016). Desain Pembelajaran Inovatif, dari Teori dan Praktik. Jakarta: PT. Rajagrafindo Persada.

Muijs, D., \& Reynolds D. (2008), Effective Teaching Teori dan Aplikasi, (H. P. Soetjipto, \& S. M. Soetjipto, Trans). Yogyakarta: Pustaka Pelajar.

Rusman. (2014). Model-model Pembelajaran: Mengembangkan Profesionalisme Guru. $\left(2^{\text {th }}\right.$ ed.). Jakarta: Rajawali Prs.

Suryawati, E., Osman, K., \& Meerah, T. M. (2010). The effectiveness of RANGKA contextual teaching and learning on students' problemsolving skills and scientific attitude. Procedia Social and Behavioral Sciences, 9, 17171721.

Sutrisno, \& Suyadi. (2015). Desain Kurikulum Perguruan Tinggi mengacu Kerangka Kualifikasi Nasional Indonesia. Bandung: PT. Remaja Rosdakarya.

Wina, S. (2006). Strategi Pembelajaran Berorientasi Standar Proses Pendidkan. Jakarta: Kencaa Prenamedia Group.

Panitz, T. (1999). Collaborative versus Cooperative Learning: A Comparison of the Two Concepts Which Will Help Us Understand the Underlying Nature of Interactive Learning. Journal of Educational Resources Information Center (ERIC). Retrieved from https://files.eric. ed.gov/fulltext/ED448443.pdf. 